\title{
A Study on Financial Difficulties and Countermeasures in the Construction of New Urbanization - Taking Yibin City as an Example
}

\author{
Li Yukun ${ }^{1,2}$, Shan Yanqiu ${ }^{2}$ Li Jing ${ }^{1}$ \\ 1. School of Economics, Sichuan University \\ P. R. China, 610000 \\ 2. YiBin University \\ P.R.China, 644000
}

\begin{abstract}
The new urbanization is an inevitable way of modernization, and the main engine to promote the sustainable development of economy. It is necessary to solve the financial difficulties and problems in the construction of new urbanization. Taking Yibin city which is located in the southwest of China as an example, this paper introduces the basic status quo of Yibin city, and then deeply analyses the financial difficulties this city is facing forward in the process of new urbanization, such as the ineffective match between supply and demand of funds, the relatively low rural financial service level, the lack of innovation the current financial models, as well as the poor financial ecological environment. At last, this paper puts forward some suggestions on improving the environment of system, perfecting the financial system, and expanding financial channels.
\end{abstract}

Keywords-The New Urbanization; Financial Difficulties; Financial Ecological Environment; Financial Models

\section{RESEARCH BACKGROUND AND SIGNIFICANCE}

\section{A. The Proposal of New Urbanization}

Urbanization refers to the process of population to urban agglomeration, urban expansion and a series of economic and social change caused by that. Its essence is the change of economic, social and spatial structure. The level of urbanization is an important symbol to measure the modernization level of a country and a region. It is said that if the urban population increases by $1 \%$, the GDP will increase by $1.5 \%$; if the urbanization rate increases by $1 \%$ every year, the economy will grow by $1.2 \%$. That is why lots of countries attach importance to promoting the process of urbanization. Nowadays, the level of urbanization in China has changed from $10.6 \%$ in 1950 s to $57.35 \%$ in 2016 . However, although the urbanization rate in China is increasing year by year, the index mainly reflects the urbanization of the population, i.e., the proportion of the urban population in the resident population. This key variable, which is based on the population' quality rather than quantity, can simply be improved by infrastructure investment, but it cannot fully and truly reflect the state of economic development of a country [1].

This paper is funded and supported by Yibin Municipal Bureau of Science and Technology in 2015.
The financial crisis in 2008 pushes China into the dilemma of insufficient power of economic growth, the surplus of production capacity as well as the lagging transformation of economic structure, and the traditional development way relied on investment and traditional urbanization must be reformed. Under the circumstances, the eighteen major reports of the Communist Party of China clearly put forward to adhere to the new road of industrialization, informatization, urbanization and agricultural modernization with Chinese characteristics. The new urbanization is the only way to modernization, and the main engine to promote economic sustainable development. Different from the traditional urbanization, the new urbanization has the basic characteristics of the balancing development in the urban and rural areas, the integration of the urban and rural areas, the interaction of industry and city development, as well as intensive and harmonious environment. Besides the pursuit of enhancing original population, the new urbanization puts forward new requirements for life level qualitative aspects, such as the economic income, equal public service, mutual promotion and integration of urban and rural. The construction of new urbanization has a long way to go, and in the process of construction, the contradiction between supply and demand of funds will undoubtedly be most prominent. Therefore, how to solve the funds problem is quite urgent and meaningful.

\section{B. Current Situation and Problems of New Urbanization Construction in Yibin City}

1) Urbanization Lagging Behind Economic Development

In recent years, Yibin's economy has developed rapidly. In 2016, the GDP reached 165 billion yuan, and the total amount continued to maintain the fourth place in Sichuan province and the first place in southern Sichuan. However, compared with the rapid growth of economy, the development of urbanization in Yibin is lagging behind the economy, which has become the gathering point of various contradictions in economic and social development. The urbanization rate of Yibin city in 2016 was $46.63 \%, 10.72 \%$ lower than the national urbanization rate which was $57.35 \%$, and $2.47 \%$ lower than the average rate of urbanization in Sichuan province which was $49.10 \%$ in 2016. From the year of 2012 to 2016, the 
urbanization rate in Yibin city has been ranked tenth in Sichuan province, and in the bottom of five cities (The five cities refers to Zigong, Luzhou, Neijiang, Yibin, and Leshan.) in southern Sichuan. The urbanization rate of Yibin and other representative cities in Sichuan province are shown in table I.

TABLE I. URBANIZATION RATE OF REPRESENTATIVE CITIES IN 2016

\begin{tabular}{c|c|c|c|c|c|c|c|c|c}
\hline & China & Sichuan & Yibin & Chengdu & Deyang & Leshan & Zigong & Luzhou & Neijiang \\
\hline $\begin{array}{c}\text { Urbanization rate } \\
(\%)\end{array}$ & 57.35 & 49.10 & 46.63 & 70.62 & 49.58 & 48.73 & 49.14 & 47.50 & 46.70 \\
\hline Ranking & - & - & 10 & 1 & 3 & 6 & 5 & 7 & 9 \\
\hline
\end{tabular}

According to the urbanization construction in Yibin, the current scale of urbanization is generally not high and unbalanced. For instance, the sizes of the built-up areas are of various sizes. The largest area is Yibin County with an area of 2940 square kilometers, and the smallest area is Nanxi District with only 704 square kilometers. Moreover, the urban population distribution is out of balance. Cuiping District has an urban population of 601,400 , while the other areas have an urban population of less than 250,000 for each. Table II shows the specific data index of the resident population, urbanization population and urbanization rate in the districts and counties of Yibin, from which we can see the urbanization rate varies greatly among districts and counties.

TABLE II. RESIDENT PopUlation, URBANIZATION POPULATION AND URBANIZATION RATE IN THE DisTRICTS AND COUNTIES OF YiBIN IN 2015

\begin{tabular}{c|c|c|c|c|c|c|c|c|c|c}
\hline & $\begin{array}{c}\text { Cuipin } \\
\text { District }\end{array}$ & $\begin{array}{c}\text { Nanxi } \\
\text { District }\end{array}$ & $\begin{array}{c}\text { Yibin } \\
\text { County }\end{array}$ & $\begin{array}{c}\text { Jiangan } \\
\text { County }\end{array}$ & $\begin{array}{c}\text { Changning } \\
\text { County }\end{array}$ & $\begin{array}{c}\text { Gao } \\
\text { County }\end{array}$ & $\begin{array}{c}\text { Gong } \\
\text { County }\end{array}$ & $\begin{array}{c}\text { Junlian } \\
\text { County }\end{array}$ & $\begin{array}{c}\text { Xingwen } \\
\text { County }\end{array}$ & $\begin{array}{c}\text { Pingshan } \\
\text { County }\end{array}$ \\
\hline $\begin{array}{c}\text { Resident } \\
\text { population(Thousand) }\end{array}$ & 852.6 & 341.0 & 771.8 & 417.0 & 344.5 & 414.0 & 374.0 & 332.4 & 386.5 & 256.1 \\
\hline $\begin{array}{c}\text { Urbanization } \\
\text { population(Thousand) }\end{array}$ & 623.5 & 172.0 & 254.9 & 177.7 & 142.1 & 154.1 & 179.2 & 120.6 & 133.5 & 67.4 \\
\hline \begin{tabular}{c} 
Urbanization rate (\%) \\
\hline
\end{tabular} & 73.12 & 50.43 & 33.03 & 42.61 & 41.25 & 37.23 & 47.91 & 36.27 & 34.54 & 26.33 \\
\hline
\end{tabular}

2) The Unconspicuous Interaction between New Industrialization and New Urbanization

New industrialization and new urbanization are supposed to be interactive and mutually promoted. However, according to the situation of Yibin, the basic motive force of industry to urbanization is still insufficient. The GDP of Yibin has been ranked fourth in Sichuan province in the recent years, while the ranking of urbanization rate of Yibin has only been ranked tenth in the province. The process of urbanization is obviously lagging behind the economic development. The main reasons are as follows:

First, the industrial development is extensive, and there are too many traditional industries or high energy consuming industries so that the proportion of high-tech industries is low, which makes the industry have a weak effect in promoting urban population agglomeration.

Second, a large part of the industrial enterprises in Yibin is coal mining enterprises, most of which are located in rural areas, so this phenomenon leads the weak agglomeration ability of urban population.
Third, the low level of industrial development has led to the low level of producer services, which failed to play the role of link bridge that the industrialization should have played in the process of urbanization.

Fourth, the characteristics of industrial parks are not prominent, the aggregation capacity as well as the adsorption effect is not strong, and the surrounding facilities are imperfect, which make the spatial cohesion of urban population be weak and the industrial parks have no obvious promoting effect on the development of urbanization.

The last but not the least, in the new urbanization construction, Yibin faces the problems of insufficient funds and single financing mode. It can be said that the reason behind the unbalanced development is the problem of funds. As long as the financial problem is solved, Yibin can speed up the process of new urbanization. Based on this background, this paper is to analyze the current financial environment in Yibin, and puts forward countermeasures to solve the financial difficulties the city encountered in the construction of new urbanization. 


\section{FINANCIAL DIFFICULTIES IN THE CONSTRUCTION OF NEW URBANIZATION INYIBIN}

As discussed above, one of the main reasons for the low urbanization rate in Yibin is that the financial environment there is relatively backward, the number of financial institutions is not large, and the support for SMEs is not enough. Since 2009, Yibin has begun to introduce various financial institutions, including CITIC Bank, Industrial Bank, Bank of Communications, Chengdu Bank, Minsheng Bank, Leshan City Commercial Bank and other banks or non-bank financial institutions. However, there is still a certain gap compared with other similar cities. The total loans are relatively backward economic development, and the homogenization phenomenon in financial institutions and business is serious. A multi-level system of financial institutions has not been formed, which failed to promote financial ecological environment in construction of the local economic development and urbanization.

\section{A. Difficult to Match the Capital Supply and Demand in the Process of Urbanization}

On the demand side, the construction of the new urbanization refers to the people's livelihood project which takes long way to go, and the construction process is bound to require substantial capital investment; on the supply side, the main funding sources in urbanization are funds raised by government or local financing platform, credit funds of financial institutions and private capital. In the process of promoting urbanization, Yibin has a limited and weak source of funds, and the existing financing channels and capital supplies are difficult to meet the capital demands of urbanization. The reasons are as follows:

First, the government funding is limited. As a city located in the less developed western region, the public financial funds, especially that in the majority of villages and towns are relatively weak and unstable. And hence, the governments in the villages and towns are difficult to raise a large amount of money for urban infrastructure construction, so that the level of urban infrastructure construction cannot keep up with the requirements of economic development, and the rapid development of urbanization in a short time could not solely rely on government financial funds.

Second, the role of local financing platform is limited. Local governments are prohibited to issue municipal bonds in China. In order to solve the shortage of financial investment, local governments established local financing platforms to raise the funds needed for construction. In 2012, the average interest rate of bonds issued by local financing platform was higher than $7 \%$, exceeding the safety standards of international consensus. To prevent risks, the CBRC (The CBRC refers to China Banking Regulatory Commission) issued a notice to stop the local governments' illegal financing behaviors, limiting the increase of local financing platforms' financing ability, which led the construction of new urbanization funded from local financing platforms to be hindered. The space of local governments' obtaining funds through the city investment bonds is compressed. Therefore, the financing ability of local governments is about to be further weaken.
Third, the financial institutions do not support enough. Although theoretically, the financing gap of urbanization can be compensated by the financial supply when the government financial funds are insufficient, the fact is that the support of financial institutions in the construction of urbanization in Yibin is insufficient either. From the statistics, Yibin's financial institutions deposits and loans are ranked sixth in Sichuan province, and first in five cities in southern Sichuan, while the urbanization rate of Yibin only ranked tenth in Sichuan and third in South Sichuan, which shows that Yibin's financial and credit support for the construction of urbanization is not relatively lagging. The funds launched to the fields of culture, education, agriculture, health, SMEs, and public services are obviously insufficient. Instead, lots of credit funds are put to the fields of manufacturing, wholesale and retail, real estate and mining. As a result, the housing price in Yibin is higher than that of the surrounding cities for a long time. To a certain extent, the high housing price increases the cost of urbanization and hinders the process of urbanization.

\section{B. The Low Level of Rural Financial Services in the Process of Urbanization}

The core of the new urbanization is the population's urbanization, which focuses on farmers, rural areas, and modern agriculture, and pays more attention to the integration of urban and rural infrastructure, the equalization of public services, and other "three rural issues". In order to solve these problems, the financial institutions are supposed to provide financial support for economic development in rural areas. However, the current financial support in rural construction is obviously insufficient, and the financial service level is not high. Nowadays, only several financial institutions such as Rural Credit Cooperatives, Agricultural Development Bank, Postal Savings Bank, county banks and some small loan companies indeed serve the rural areas in Yibin. Due to the commercial restructuring in recent years, the Postal Savings Bank changed the service scope into enterprises and individual industrial which are more profitable. County banks and small loan companies, which could not afford the infrastructure construction in rural areas, are limited to fund small and micro enterprises. On pursuit of profits, the Rural Credit Cooperatives are more and more inclined to loan the urban credit fields, and decreases financial support for the rural areas. As the only policy-based financial institution in Yibin area, the Agricultural Development Bank affords too much and because its limited business coverage and financial innovation ability, its investment funds and support function are far from enough.

\section{Insufficient Innovation of Financial Institutions in the Process of Urbanization}

The lack of products and services innovation ability of financial institutions in Yibin has become the biggest obstacle of financial support in the process of urbanization. First, driven by stress of market shares and profits, financial institutions innovate financial products and services for the purpose of maximal profits, so they are lack of sense of social responsibility and tend to ignore innovating financial products and services in urbanization which represents the public and 
social welfare. Second, financial innovation products are impractical and hard to meet the local financial demands in urbanization. The product development authority is concentrated in the headquarters of financial institutions, and the headquarters are usually set up in developed regions. The financial products developed for the urban construction may solve the financial difficulties in the developed region, but they are hard to take the financial demands in underdeveloped areas into consideration. And thus, the innovative products could not match the financial demands and the technical level of financial services in Yibin. Third, the threshold of most rural financial innovation products is relatively high. For instance, although some financial institutions have developed rural credit services for small and medium-sized enterprises in the counties, such as "chattel mortgage", "warehouse receipt mortgage", " project expected revenue pledge" and other financial products, the thresholds are overall higher, because the borrowers must have the high quality of movable or immovable property, a relatively stable expected net cash inflow or higher reserve, which will undoubtedly shut many small and micro businesses and rural financing demand out. In addition, some financial products and innovative financing models become increasingly complex, which are beyond the understanding of some rural residents, and to some extent, suppress their financial demand.

\section{Financial Ecological Environment Hindering the Development Speed of Urbanization}

In order to promote the efficiency of Finance in the construction of new urbanization, it is necessary to build a healthy and favorable ecological environment for financial development. Financial ecological environment includes administrative environment, civil rights and obligations, social integrity and other elements. The lack of any elements will destroy the integrity and health of the financial ecological environment. The administrative efficiency and executive ability of villages and towns in underdeveloped areas need to be improved. The Chinese citizens, especially those in villages and towns lack legal awareness, rights and obligations awareness, as well as awareness of safeguarding rights and supervision, which are not benefit to the efficient operation of urban financial organizations. Besides, the phenomenon of credibility and integrity deficiency is very serious. Breach of contract, private lending disputes, and the bankruptcy of financing guarantee corporations as well as P2P platforms occur normally. Such phenomena cause unharmonious and unstable factors to financial ecological environment, and hinder the development speed of new urbanization.

\section{COUNTERMEASURES TO SOLVE THE FINANCIAL DIFFICULTIES IN THE URBANIZATION CONSTRUCTION}

\section{A. To Improve Institutional Environment}

The government should improve the original design defects from the aspects of policy and system, increase the financial guidance, and create a high quality financial environment for the rapid urbanization construction. First, improve the urban management and programming level especially in small towns. Launch a pilot project and scheme in economic development zones or Industrial Park and give supporting policies if the industries or projects are development oriented and in line with the overall urban planning. Moreover, the government should simplify approval procedures, shorten the approval time, and finally improve work efficiency. Second, the land security policy should be improved. Give priority to those construction projects which accord with the urbanization construction in the annual land planning. Increase the land planning target in urban construction, and invest part of land transfer income in rural infrastructure and public facilities construction. Third, we should increase the amplification function of fiscal and taxation policies on financial investment. Implement financial subsidies, preferential tax or even tax relief policies to enterprises engaging in public utilities and infrastructure projects, as well as energy conservation and environmental protection projects. Finally, in the spirit of the document about the promotion of government and social capital cooperation mode, which is issued by the Ministry of Finance on September 2014, it is necessary to innovate some feasible PPP financing modes and relevant policies such as issuing franchising rights, purchasing services and equity cooperation in order to encourage social capitals to participate in the construction and management [2].

\section{B. To Perfect Financial Systems}

The construction of the new urbanization is a process of rapid concentration of resources and elements, covering all kinds of municipal infrastructure, public services, housing construction and so on [3]. In this process, a large amount of capital is required to investment the city infrastructure, public service system, indemnificatory housing construction, occupation training and the development of modern agriculture. To solve the problem of capital in the process of urbanization construction, the most important thing is to establish a sound multi-level financial support and security system. At present, the financial system could not meet the needs of urbanization construction in Yibin, because it is difficult to meet the funds demand for comprehensive urbanization construction only relying on the government's financial capital and bank credit funds. Therefore, the government should innovate and improve the existing financial system as soon as possible. For instance, on the basis of regulatory and policy guidance, the government should establish a multi-level capital market, gradually introduce diversified financial institutions into the relatively remote and backward areas, such as policy banks, large commercial banks, joint-stock banks, securities companies, trust companies, insurance companies, county banks, small loan companies, private investment and finance companies. And hence the 
government could promote the development of hospitals, education, health care and other infrastructure and public services, and thoroughly solve the financial difficulties in the new urbanization construction.

\section{To Expand Financing Channels}

First of all, the government should increase their own financial recourses. It is necessary to increase local revenue through coordinating the central and local tax revenue, and explore the municipal bond issuance pilot so as to gradually promote the expansion of local government funding source based on a rigorous assessment of repayment ability and credit risk. Besides, develop the special industries in each county to develop the county economy and increase the county revenue, and thoroughly break the financial deficient embarrassment. Moreover, play the function of such politic financial institutions as Agricultural Development Bank and the National Development Bank in the process of urbanization construction. Third, we should guide commercial banks and other financial institutions to carry out inclusive finance properly [4]. Effectively encourage financial institutions to provide products and services for small and micro businesses and the rural poverty, and increase their credit support to public service facilities, modern agriculture, and urban construction. At last, broaden the scope of private capitals to participate in urbanization construction, and increase the intensity and modes innovation of government and private capital cooperation. On the purpose of actively applying the social idle funds in urbanization construction and realize the effective allocation and full use of resources, encourage private capitals to enter the urban and rural infrastructure, indemnificatory housing construction, city water as well as other public services supply, sewage treatment and emission reduction projects through policy guidance [5]

\section{CONCLUSION}

The problem of funds is the major problem to be solved in the construction of new urbanization. In the process of transformation and industry upgrading, the traditional financial ecological environment and the traditional indirect financing model represented by bank-oriented cannot meet the demand of the new urbanization construction. Taking Yibin city as an example, this paper deeply analyses the financial difficulties it is facing forward in the process of new urbanization, such as the ineffective match between funds' supply and demand, the relatively low rural financial service level, the lack of innovation in the current financial models, as well as the poor financial ecological environment. In order to solve the funds problems, it puts forward some countermeasures such as improving the environment of system, perfecting the financial system, and expanding financial channels. Only in this way can Yibin accelerate the transformation and development of new urbanization, take the lead in building well-off society in an all-round way, and also realize the "2365 Yibin Dream".

\section{REFERENCES}

[1] F.S.Cai. Spatial Patterns of Migration under China's Reform Period [J].Asian and Pacific Migration Journal,1999.

[2] Cao Fengqi. The New Urbanization and Financial innovation[J].Finance Forum, 2013(7):3-6

[3] Kyung - Hwan Kim. Housing Finance and Urban Infrastructure Finance [J]. Urban Studies, 1997,34(10).

[4] Li Jianhua. Research on Financial Support in the Process of Urbanization $[\mathrm{J}]$. Technoeconomics \& Management Research, 2014(10):102-105.

[5] Li Wen, Zhuang Yaming.Comprehensive Measurement and Financial Support of New Urbanization Construction in Western China[J] Inquiry into Economic Issues,2017(1):72-81. 